Creek. By Monday morning, everything was frozen solid, so that we could go where we pleased, and we stárted for Fort Dodge where we arrived in due time without incident or accident worthy of notice.

\title{
THE FIRST MONUMENT TO IOWA VALOR.
}

BY CHARLES ALDRICH.

The first effort to do honor to the memories of the hardy pioneers who volunteered in 1857 at Webster City to go to the relief of the settlers at Spirit Lake who had been attacked by the ruthless Sioux Indians, was undertaken by me in the summer of 1887. Having been a typesetter for many years, I came in one day from my farm and asked the proprietor of the Webster City Freeman to make up a stick the width of a sheet of old-fashioned letter paper, and give me a case.

He did so at once, and I then and there set the type for a brief petition to the county board of supervisors, praying for the appropriation of three hundred dollars with which to procure a tablet to the memory of the soldiers as above stated. When I had set the type, Mr. Hunter kindly had three or four copies of the petition printed. This was on a Saturday.

I first went to the banks and secured the signatures of all the bankers with two exceptions. After those of the bankers I secured the signatures of the leading merchants. Many of the leading farmers of the surrounding country were in town that day, and every one to whom I presented the petition signed it cheerfully. In this way I secured the endorsement of perhaps thirty or forty of the representative tax payers of the county.

Charles T. Fenton was chairman of the board of supervisors and read the petition. He remarked, " $O$, yes, we will grant that petition." His associates assented to the proposition. They then proceeded to appoint me as a committee to carry out the prayer of the petitioners. I objected to acting alone, but said I would be willing to do the work provided they would give me four or five associates. 
This proposition was accepted and they asked me to name the gentlemen whom I desired to act with me. The following were named by me for this work: Ex-Judge Daniel D. Chase, Kendall Young, W. W. Boak and Augustus Anderson. I prepared the inseription which the Judge and I discussed a half hour or more. He finally gave his endorsement to the lettering as it stands on the tablet today. I entered at once into correspondence with Messrs. J. \& R. Lamb, 59 Carmine Street, New York City, who offered to manufacture a tablet for two hundred and fifty dollars, furnishing also a beautiful slab of blue Champlain marble upon which to mount it. I accepted their offer and closed the contract with them.

I decided on August 12th as the date upon which to unveil and dedicate the tablet. My first step was to invite Gov. William Larrabee to be present and preside over the meeting in the courthouse. He was very much occupied but finally promised to come.

In order to make the occasion of the utmost historical importance, I invited six gentlemen who had participated in the Spirit Lake Expedition to be present, and read to the people chapters of their recollections of the expedition and all the attending circumstances. These were Ex-Governor Carpenter, Hon. John F. Duncombe, Commander of Company $B$ in the Expedition, and Charles B. Richards of Fort Dodge, Commander of Company A. Then we had the following privates from our own county: Michael Sweeney, William K. Laughlin and Frank R. Mason. Each of them wrote out his recollections and read them at the unveiling of the tablet. These articles were quite largely copied by newspapers of the State at that time and attracted wide attention. Some years afterwards I compiled them into one long article which I published in the ANNALS, ${ }^{1}$ and this I confidently believe gives the best account of the Spirit Lake Expedition that has ever been published. Herbert Howe Bancroft somewhere states in his great works that the best material for historical purposes are these records of eye witnesses. I also included the portraits of several of these men.

\footnotetext{
${ }^{1}$ ANNALS OF Iowa, 3d.ser, v. III, p. 481-553.
} 
Upon assembling at the courthouse, I was at first a little fearful that I had procured "more speeches" than could be delivered during the afternoon. But upon organizing the meeting in the court room, I soon ascertained that we could only get about one-third of the people present into that hall. The only resource therefore was to organize an overflow meeting on the east front of the edifice. This was speedily done, and the great crowd outside drew up close to the entrance where they were first addressed by Ex-Governor Carpenter, followed by Hon. Wesley Martin who read the article which had been prepared by Michael Sweeney, then absent in Colorado. Lieutenant Maxwell, who had delivered his address in the court room, came down and delivered it again to the outside meeting. I had prepared a statement given to me by. Mrs. W. L. Church, the brave woman who killed an Indian near Springfield, now Jackson, Minnesota.

The event passed off to the satisfaction of all present. The tablet was a very fine one, and it remains where it was placed on that eventful day. It is estimated that there were more than two thousand people in attendance, ably presided over by William Larrabee who was then at the height of his almost phenomenal popularity as governor of the State.

I believe that this was the first effort to erect a historical memorial within the State of Iowa to men who had served in a military capacity.

A pretty brisk trade is now carried on between this place and Illinois, in consequence of the very accommodating natural bridge that has recently been erected across the Mississippi. Were we telling this story in Siam we might be obliged to explain, but those living in cold countries will doubtless understand us.-Burlington, I. T.-Burlington Patriot, Dec. 13, 1838. (Prospectus) 
Copyright of Annals of Iowa is the property of State of Iowa, by \& through the State Historical Society of Iowa and its content may not be copied or emailed to multiple sites or posted to a listserv without the copyright holder's express written permission. However, users may print, download, or email articles for individual use. 